\title{
Different Attitudes in Different Regions Aimed at Military Personnel in Turkey
}

\author{
Sinan Çaya ${ }^{a}$
}

\begin{abstract}
Historically Turks had always relied on military power. The culture is rich with martial values to this day. Even each civilian is somewhat soldierly in a sense, in general. Nevertheless, in a more detailed analysis, in some territories of the country, the prestige enjoyed by the military is more intensive than the average, while in some other territories, respect for military people is much below the average tendency. One might infer that in the former category, it is a question of the regions where the inhabitants are mild, soft-spoken, and compatible. They accordingly admire discipline and display obedient attitudes vis-a-vis governmental authority ever since the Ottoman times, merely as a cultural and traditional trait. Those regions are certainly places where military people today are held in high esteem. In such locations, even the ideal profession for a little boy is indoctrinated as a military career, by the whole family or the surrounding social environment. It should be mentioned that in certain cities and towns, a substantial percentage of the population are represented by immigrants, who got re-patriated along the course of the near history, as the former Ottoman Empire began shrinking in territory due to loss of land, during successive wars. The crushing majority of the Muslim Ottoman subjects in those lost territories preferred leaving their property and escaping into the Anatolian mainland, rather than renouncing their belief and assimilating to the new political regime. Having suffered at the hands of foreign powers, those people have also been especially appreciative of the value of their own soldiers. As for the latter category, dislike of discipline and authority can be mainly attributed to the special social structure and historical circumstances.
\end{abstract}

\section{Keywords}

Attitude, region, military

Turks are known to be a military nation. In history, they had to fight all their way from Central Asia to Minor Asia and later even onto mid-Europe for a time. The military is probably the oldest and the very most important instution. The culture is accordingly emedded with martial motifs and ideas. Turkish people love and respect their soldiers. Each man had been conscripted into service himself and preserves military traits long after his discharge. All male teenagers know that in the near-future, they will end up in the service. Mothers and fiancees are well aware of as well as proud of this fact.
The average Turkish citizen has more confidence in the military than in any other institution. When young men depart from their homes for the army service, people farewell those draftees/concripts in exuberant ceremonies, crying out the slogans like

\footnotetext{
astanbul University, Turkey

Correspondent Author:

Sinan Çaya, Instructor of Social Graduate Elective Courses at Istanbul University, Institute of Marine Administration and Sciences, Istanbul, Turkey

E-mail: sinan.caya@gmail.com
} 
"Our soldier is the greatest soldier" (En büyük asker bizim asker). But, for all this ever-present feeling of dense sympathy, certain geographical regions are known to nurture even a more accented love and respect for the military.

\section{THE MID-ANATOLIAN CITY OF ÇANKIRI}

One such province is Çankırı in Central Anatolia. Here, appreciation of martial values are seen to be stressed in the local culture: Çankırı and Eldivan youths face no difficulties in military service. This is achieved in accordance with the "yârân" tradition" [The custom is related to the historical artisan guild associations (âhilik) and the para-mlitary culture of "seymenlik" upholding physical bravery in ritual assemblies of men]. Young lads are initiated into discipline and obedience as well as to hard conditions of existence. The "seymen" tradition in Eldivan county fully preserves martial traits. Marches, commands, work discipline, valuing seriousness are all of military nature. Punishments are executed in outdoor conditions, which also are an opportunity facilitating adaption to the military environment. Acting everywhere and all the time in military order, respect for the elder, mutual love among comrades were, after all, included in Janissary customs (Tezcan 1974: 411).

\section{THE REGION SURROUNDING THE INTERNAL SEA OF MARMARA}

Another province holding soldiers in very high esteem is known to be Adapazarı. After a devastating earthquake hit that region in 1999, many news clippings mentioned about the pople's longing for new military units to boost the local economy and help the city recuperate from the inflicted damage. One subtitle was indeed quite romantic: "Adapazar1 is in wait of soldiers, watching the entrance roads!". This is an allusion to a famous ballad (folk song): "Asker yolu beklerim/Günleri saya saya" (My eyes directed to roads, I'm waiting for the return of my soldier, my lover/Here I am, counting the days drift by!).

Here is one related case history about the city's fondness for soldiers. A friend of mine, Mehmet Sirr1, three years older than me, had done his military service in Sakarya. As he narrated it soon after the completion of his service, people in Adapazarı adored soldiers! One afternoon his platoon was returning to the barracks after tiring drills, through the side streets of a far-flung neighborhood in casual gait (âdi adım). An elder lady with a smiling face met the commanding officer and offered to serve tea for the soldiers (The lady knew to whom she should address. Even this minor point is interesting). They sat down on the pavement, leaning their backs to the outer walls of flat, humble housings and enjoyed the delicious tea! The elder lady (whom reminded Sirr of his own grandmother) took great delight in serving them as she kept saying "here are my sons" (evlâtlarım gelmiş).

A farmer named Hasan narrated the following in a coffee-house in the coastal city Tekirdağ (August 18, 2001) said:

In 1963 and 1964, I did my military service in Adapazar1. The local people, the citizens, and the shop-keepers were very kind to us, the soldiers. As a matter fact, when the Cyprus crisis broke out and we ended up at the nearby Arifiye train station, loading the equipment of distinguished troops from Bolu (now they are called "ommandoes", I think; then the term was not used, you know; as for me, I was a transportation soldier), what did I see? The people took everything worth to offer from their houses and brought them to the station to give us: biscuits, cookies, liquid-yoghurt in bottles, mineral water and so forth.

The aim was to ship the soldiers and the equipment by train all the way to Mersin. This was the time when Captain Cengiz Topel's jet-plane fell down and the pilot lost his life. The situation appeased after some time, though. 


\section{THRACIANS LOVE THEIR MILITARY}

As for Thrace, this region's sympathy for the military values can best be verified by a single fact: No father ever consents to give his daughter in marriage to a young man, before completion of his military service. [Moreover, it is much more difficult to endure the military service as a married man (see Figure 1)].

In the Thracian village of Büyük Mandıra ${ }^{2}$ (where the majority of the population are descended from emigrants coming from Plevne, following the Ottoman-Russian War of 1977-1978), a moving époée used to be regularly recited by young lads going to the army service. The époée is in Pomak language (and here it is spelled out phonetically, just as it sounds to the ear). The tradition was kept until about late 1940's (The new generations are more and more forgetting that language):

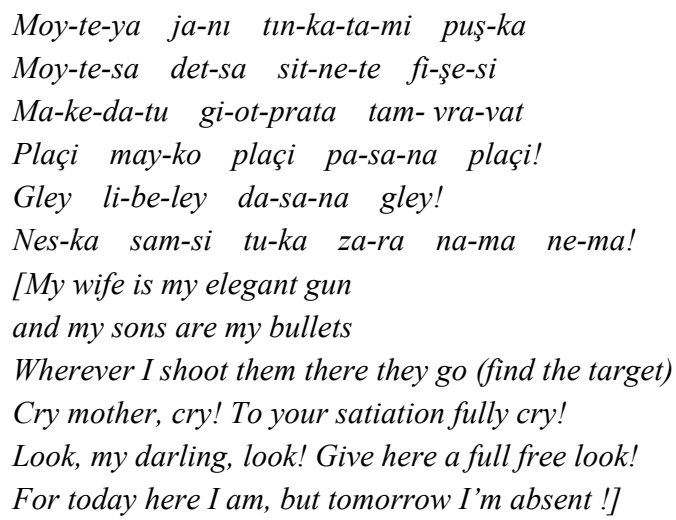

The general world view and more modern tendencies of the Thracian Turks render them somewhat different from the rest of the country. Here, Eastern ways like large families (the bride moving into the groom's family), tribal structures (which are "primitive and evolutionary stages of human organization"), blood feuds, wedlock between relatives $^{3}$ are non-existent. Segregation of the two sexes, which is common elsewhere, is not a rule, females do not avoid social interaction with males (lack of kaç-göç). Domination of big landlords and so-called religious figures is not to be seen. In brief, the population of the Thrace is far from being an umma (ümmet) and display true traits of a nation, in the Western sense of the word. Loyalty to national institutions and especially to the Armed Forces, defender of the nation, is just a natural consequence of such a long social developmental process.

The following extract from the writings of an outstanding scholar, Şengör (1999) is a very enlightening interpretation regarding the historical contribution of this region to the formation of modern Turkey: (Journalist Hasan Tahsin was martyred in İzmir by Greek-invaders in May of 1919). The point which regards me here is that Hasan Tahsin was from Roumélie (Selanik). So, just like Mustafa Kemâl, who led to success the big rebellion in Anatolia, he who ignited the first spark was a Roumélite. The purpose of this article is to stress that this is no simple coincidence. Especially during the last 30 years of the nineteenth century, Roumélie was decorated with high quality schools. In Roumélie, agriculture was fairly modernized with respect to Anatolia and commerce was common among Moslem Turks, also.

People were richer than those in Anatolia, their interaction with the world, their knowledge and culture were more advanced. Feudal structure was lost. Though the Roumélite could not catch up with the rest of Europe, at least, he knew his own locus as well as the situation of the world. It is a known fact that Atatürk, while in exile in Syria, escaped to Selanik in the end of the year 1905, since he saw the "most convenient climate for freedom" only in Roumélie. When Mustafa Kemâl heard (many) soldiers drifted away just before the Battle of Sakarya, he did not get furious but just said: "You see, if you leave a nation ignorant and unconscious for centuries, this becomes the result". What is needed to make a nation a real nation is education, an education which drives from a critical mind, which teaches the products of civilization, which is scientific and of high quality and widespread (Şengör 1999).

Many distinguished commandants of the Armed 


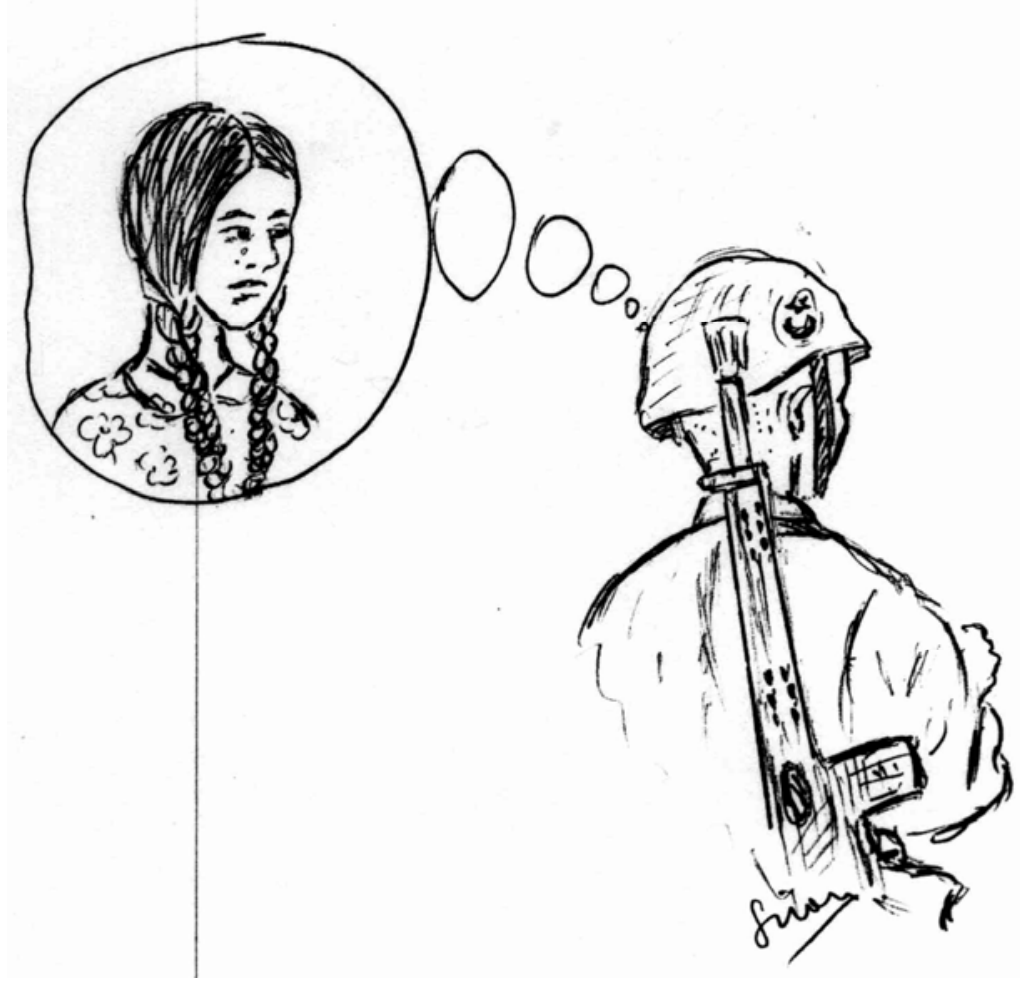

Figure 1. A Conscripted Soldier Daydreaming About His Sweetheart Left at Home. In Thracian Villages, as a Rule of Thumb, Families Never Give Their Daughters to Suitors Before the Completion of the Service. In Other Regions, They Mostly Do so. This Practice Also Serves the Purpose of Insuring the Young Men's Return, But It Renders the Service All the More Difficult. Source: illustrated by the author.

Forces are of Balkanic origin. Even some names reveal this fact. For example, late full general İ. Hakk1 Tunaboylu (former chief-of-staff, graduation date from Kuleli Military High School: 1913, he passed away long ago) and the late Full General Hüseyin Doğan Özgöçmen (former army commandant, date of commissioning 1934, following a long retirement, he passed away recently, on August 15, 2001, in İstanbul). ("Tunaboylu" means "from the shores of the Danube river"; "Özgöçmen" means "true-emmigrant").

Atatürk himself comes from Selânik. As Kutay (1947) narrates us, in a merry party at night time, a citizen asked Atatürk: "A be! (a local exclamation approximating "well now”) Paşam (my general) I am curious to know. Then in Kocatepe, you had given the order 'Armies, your first target is the Mediterranean!'. In that case, just what is the next target?". With a mild expression on his face, Atatürk contemplated this naïve, candid man; who obviously (judging from his accent) came from Roumélie. Then he raised his glass of raki (Schnaps) and replied: "Well now, my compatriot, take it easy! Let's first drink in honor of that first target!".

\section{THE AGEAN CULTURE DOES NOT EMBRACE THE MILITARY}

As a final point in this paper, it may be said that in some regions, where the vestiges of the traditional "zeybek" culture (see Figure 2) prevails, young man might have more difficulty in adapting to military life. 


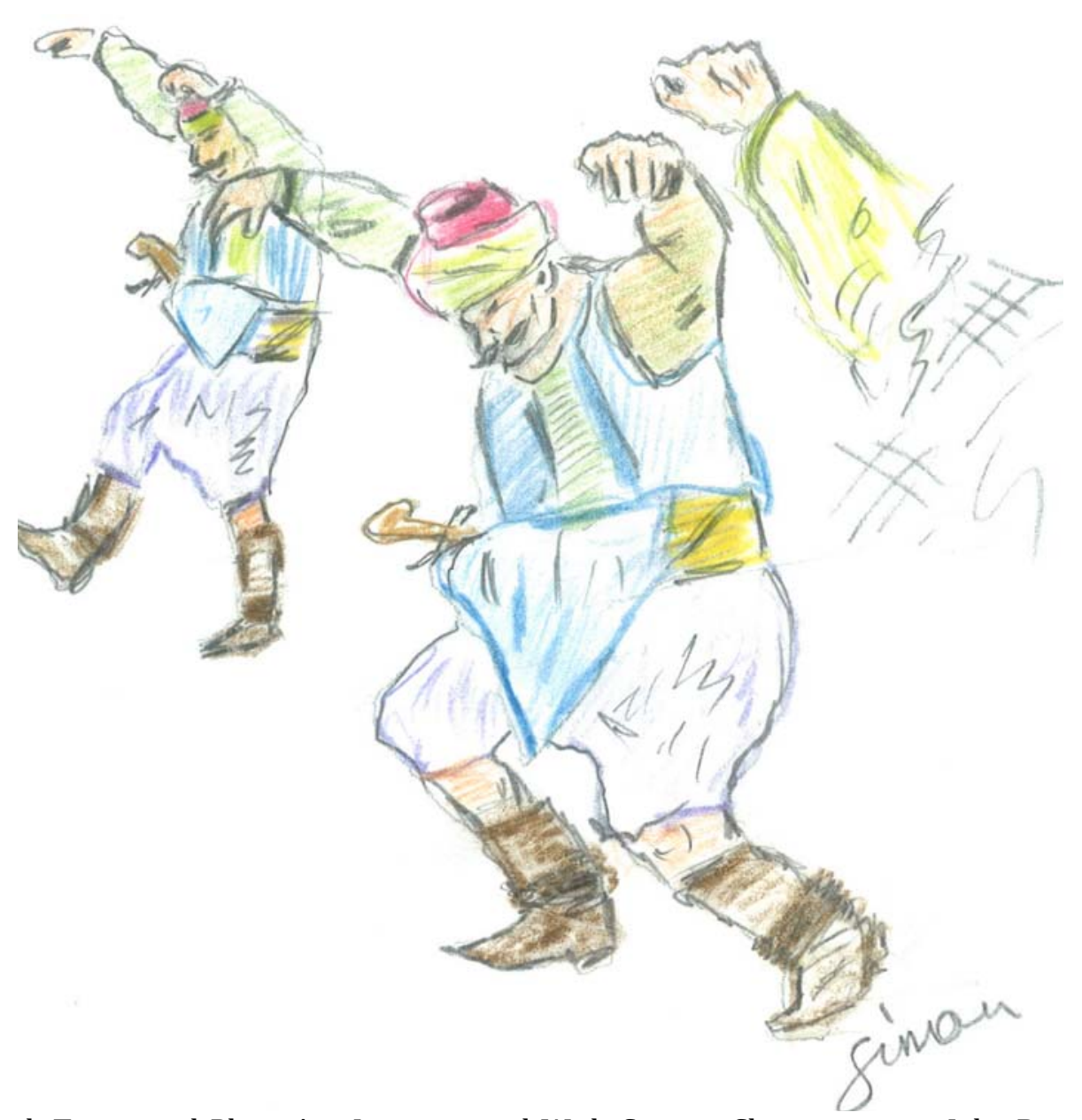

Figure 2. Zeybek Tunes and Plays Are Impregnated With Certain Characteristics Like Being Heavy, Slow, Prideful and Defying. Source: illustrated by the author.

It is paradoxical in the sense that "zeybeks" were brave men highly capable of handling weapons of all sorts. They were fond of bravery. They loved horses. However, their challenging airs, and exaggerated love of personal independence were not prone to submit to martial discipline. This is where the "catch" lies. Their animosity toward official authority was invariably turning to military symbols since a very conspicuous representation of authority is embodied in soldiers. Another irony lies in the fact that some of them were among the first men to put up arms against the Greek invaders, while some of them also got involved in internal revolts (provoked by the so-called
Caliph-Sultan's men).

Bayraktar (1991: 152) says that even names like "efe" or "zeybek" were euphemistic titles undeservingly sublimating their popular image, the origin of those ignorant village boys reaching out to the bandits of the eighteenth century. He mentions that their participation in the resistance must have been at least partly based on the fear of the would-be future order of the invaders.

Nevertheless, it is a fact that the officially-opressed ordinary people usually did welcome those outlaws as heroic saviors and glorified them in folk ballads and songs. Story-writer Aras 
Ören likes to write about his famous character Bekir Uçal, who comes from an Aegean small town and is a guest-worker (Gastarbeiter) in Germany. The man is very similar to the unforgettable Walter Mitty character of James Thurber. He has a fantastic imagination which is always working. One of the peculiarities of Bekir is his passionate indulgence in narrating folk epopees dating from his childhood days. His favor story is about Çakircali Efe (1877-1911), his compatriot. Bekir learned about the hero directly from the youth reminiscences of a former Ottoman gendarmerie-conscript in his county. It is given as follows by Ören (1984: 14-15):

Once we encircled Çakırcalı Efe at a far-flung village, which used to provide shelter for his gang, from time to time. Upon the given orders, with a bunch of comrades-in-arm, we rushed to a two-floor village-house for a search. A woman with a headscarf opened the door and froze like a stone statue. Only her eye movement indicated the upper floor. Three of us climbed the stairs while the other two stayed at the gate as sentries. We encountered the hero of heroes with the lion-face, just at the top of the stairs! His eyes were gazzling underneath his fez ${ }^{4}$.

—_Whom are you looking for?". He roared.

Panic enslaved us. Then he went speaking placidly.

- "Have you ever seen Çakırcali Efe? And what the hell do you want him for, you lowly chained-dogs?".

My knees were trembling as I answered.

- No, my noble lord, us, the order-takers, we have never seen him. We wouldn't have recognized him even if we had seen him".

- "In that case, go tell your commandant that you neither saw nor found him". He ordered.

We descended the steps and joined the two sentries, who also had heard the encounter and were soaring in perspiration due to immense fear. We all eyed one another without uttering a single word. We then ran to our officer and simultaneously gave the oral report about having seen nobody within the specified village-home.

In one scene of the Turkish movie titled "Şaban Askerde" (Şaban in the Army) starring the defunct comedian Kemal Sunal, the inspecting general scolds the master sergeant: "You zeybek-looking man! What is that moustache? Shave it off! Right now!”. Here the zeybek association is interesting. (Nevertheless, ever since late $1960 \mathrm{~s}^{5}$, no military person of any rank is allowed to have a moustache, not even on holidays, so, this point was one of the few factual mistakes in that excellent movie).

Atay (1968) analyses them more leniently. $\mathrm{He}$ says "Certainly members of gangs were foremost among the first heros of the national forces in the West". He adds: "The esteem in which the gangs were popularly held lasted until it became clear that they were useless against the Greek advance".

A certain gang leader was Edhem. Though of Circassian origin, his activities took place in the West, Aegean region. He made enormous contributions to the national cause at first, however, a very egocentric man and a slave of his own insatiable ego, he absolutely refused to be placed under the orders of the newly-established regular army. Eventually, he defected and took shelter among the Greeks. He can be compared to an infamous character in the American War of Independence:

He was a gambler who fought best under pressure of fearful odds. Physical danger exhilarated him. Once on the verge of falling prisoner, he killed the enemy rifleman with his gun and escaped. In another battle, he almost lost his leg. While the military governor of a hostile city, he got charged with financial misconduct. The court-martial found him not guilty of major charges. But he was re-assigned as the commander of a fort along the Hudson River. He resented this passive task. Urged by his young wife, he finally negotiated the betrayal of the fort with the enemy, believing the British would recognize his true worth. His name is synonymous with "traitor": Benedict Arnold. For all his physical courage, he lacked moral courage to resist temptation and keep his principles. The man was lost under organizational, individual, and situational stress. A pharmacist by trade, he was not trained as a military leader (paraphrased from Field Circular Development Program, Military Professionalism September 1984, pp. 4-5 through pp. 4-7)

Along with Edhem, other zeybek leaders like Demirci Mehmet Efe also revolted, upon the re-establishment of regular forces, which had been 
abolished after Mudros Armistice. Yörük Ali Efe ${ }^{6}$ was one of those militia leaders who stayed and gave his consent for the newly-assigned rank within the bosom of the hierarchical new army. It is told that in his bandit days in late Ottoman times, once he had escaped from the gendarmes by clinging to the sides of an improvised raft drifting on the cold waters of a river in winter time. The brave man was a perfect shooter with his rifle, as well. He survived the Independence War and lived until 1951, embracing the official title of a heroic veteran.

Vestiges of the zeybek culture are still lingering and sometims affecting the local peaple's dealings with the military. In the city of Burdur, about a decade ago, the boot camps novices quarrelled with the shohkeepers and their weekend leaves were suspended for a time by their commandant. It is not difficult to infer that the events could have been provoked by the shop-keepers negative attitude toward the conscripts.

It will not be wrong to affirm that the city of Kütahya does not fancy military people much, either. Some years ago, one of my friends was stationed there as a summer-trainer in a state-owned chemical plant. One day, the military national football team was playing against the city's second league team and he was passing by the stadium. The cheerings of the spactators against the military team was an amazing experience for him.

At the time he once paid a second visit to a particular pudding shop to taste again a delicious dish of dessert. This was a rare version of ekmek kadayifi soaked in a red-colored syrup. This time though, the same shopkeeper's behavior was distinctly different than before. The shop-keeper openly and obviously maltreated the young friend of mine, besides doing other things, at the moment of payment, the shop-keeper also tossed the change-money onto the counter without a thank-you-word, in the end. When the young student left the shop, his face was so long that it was touching to his knees! He tried to think why he had been perceived as such a repulsive person and the pieces of the puzzle soon fell together. He realized that he had just had a crew-cut. Judging from his very short hair-cut, the man doubtlessly took him as a military person in plain clothes!

In a pie-graph giving the percentage of cadets at a certain military highschool, the slice representing the Aegean region is relatively thin with respect to slices representing the Marmara, central Anatolia, and the Black Sea regions. Nevertheless, few Kütahya boys who once enter such schools become very good officers and petty officers. Maybe because they need to prove themselves, they try harder. Sometims, the so-called opposite poles may have a lot in common. As Psychologist Cüceloğlu (1999: 303) puts it, socially unaccepted aggressive tendencies change form and are re-expressed through sublimation. So, if a person who likes to bully others becomes a watchman or a policeman, this behavior of his is regarded as part of his work.

When the author made an interview with a famous elderly painter from Kütahya a few years ago, he got spoiled along the course of the talks and dared ask about his father's profession. The artist is inspired in most of his paintings by local sceneries from his homecity, Kütahya. In fact, he came to be known as the painter of this very city. He literally identifies himself with the city. In no written literature was his father's job ever mentioned and the author's curiosity was aroused. Finally, the author became proud to "squeeze" the answer and the painter's previous taciturn insistance now made some sense.

His father had been a "zaptiye" (Ottoman gendarmerie) corporal during the last years of the Ottoman State. He had worked in the province of Tavşanlı. The spirit moved the painter and in a nostalgic mood, he related that his father had been an honest but stern gendarm. At the time, one of the tough youths of the town had once said to his father: "We had been too frivolous and you were the one who could finally 
discipline us and pull us together, corporal!".

\section{CONCLUSIONS}

Attitudes develop in long time and are "shaped" through cultural and historicals happenings. Accordingly, even a most prevailent public feeling like love and respect for the military, undergoes some changes from one region to another rather than displaying a constant intensity throughout the country.

\section{Notes}

1. The "yârân" tradition has its roots in Central Asia. The Ottoman gilds contributed to the customs after acceptance of Islam. "Yârân" is a cultural complex including entertainment, relaxation, mutual help, education, social solidarity and fine arts like music and (verbal) literature. A "seymen" is a "yârân" member. Today, their main function is to keep good order in wedding ceremonies and offer escort to the bride until she safely reaches the groom's house. Formerly seymens had swords. The tradition includes corporal punishment like getting beaten by the elders (Further explanation gleaned from the rest of the article of Tezcan, May 1992). Mustafa Kemal Pasha was met by seymens as he entered Ankara for the first time during the national struggle. On that very same spot, a monument is erected. The place, today, is just at the entrance of the chief-of-staff of the Armed Forces.

2. In July 1984, Staff Colonel Ali Meralcan, then commandant of the Tenth Armored Regiment in Kirklareli said the following words in an assembly with his officers: "For the anniversary of Çanakkale Victory, which we celebrated four months ago, I had intended to fetch here a veteran ("gâzi") of that battle. I had made a screening of the whole Thrace to find one. By great chance, in the village of Mandira I found not just one, but two together!". So, it was the honor and the sacred luck ("nasip") of that very same village, to provide two veterans for the victory ceremony held on March 15, 1984, in the Tenth Armored Regiment in Kırklareli. The action in Gallipoli had occurred in 1915. The two gâzis therefore must have been at least 89 to 90 years old at the time.

3. The Western part of Thrace stayed outside the present boundaries of Turkey. The Moslem and Turkish population pools there also bear the same social traits as the Eastern Thracians. Çavuşoğlu (1993: 151) notes that among
Pomak-Turks and generally in other Turkish groups in the Western Thrace, a very meticulous rule is to avoid marriages between blood-relatives.

4. The Ottoman fez/Filzhut got abolished after the Republican reforms, under severe penalty. Nevertheless, as Yashar Kemal depicts it in his novels, on the Taurus mountains, bandits deliberately kept wearing this particular head covering as a further sign of defiance of the legal authority.

5. The order banning the moustache was issued by then chief-of-staff, Full General Cemal Tural. In former years, an officer or petty-officer could grow a moustache if permitted by their immediate superiors. The author's own father has a moustached photograph (taken in Erzurum in mid-1950s) in his tanker-captain uniform while he is holding him (then an infant) on his lap.

6. Some years ago, a realistic life-size statue of Yörük Ali erected in his Aegean town, raised a lot of controversy because of his lack of a moustache. Until the first years of the Republic, just like in the entire Near East, one could see no cleanly-shaven-men on the streets, only the eunuchs (castrated male-servants) being the exception. If not a beard, then at least a moustache was the rule of thumb. Now, the heroic man was beardless (imberbe, bartlos) in actuality, in accordance with the statue. Nevertheless, the still-lingering macho-culture of his compatriots caused provoked a lot of indignance and fury.

\section{References}

Atay, F. R. 1968. The Atatürk I Knew (An Abridged Translation by Geoffrey Lewis of the Original Work Titled Çankaya). Istanbul: Binbirdirek Matbaacılık Sanayii A.Ş.

Bayraktar, B. 1991. "Millî Mücadelede Denizli Olay1" (The Incidents in the Egean City of Denizli During the National Struggle). Atatürk Araştırma Merkezi Dergisi (The Journal of the Center for Atatürk-Research) 8(22). Ankara: Atatürk Araştırma Merkezi (Center for Atatürk Research).

Çavuşoğlu, H. 1993. Balkanlar'da Pomak Türkeri, Tarih ve Sosyo-Kültürel Yapı (Pomatsi-Turks in the Balkans, Their History and Socio-Cultural Structure). Ankara: KÖKSAV Publication.

Cüceloğlu, D. 1999. Insan ve Davranışı (Man and his Behavior). 9th ed. İstanbul: Remzi Bookstore.

Field Circular for Program Development About Military Professionalism. 1984. Fort Leavenworth, Kansas: U.S. Army Command and General Staff College publication.

Kutay, C. 1947. "A Be Hemşerim" (Well, Now, My Dear Compatriot). Millet, Siyasi Dergi (Nation, a Political Journal) 11:13.

Ören, A. 1984. Manege: Erzählung (Horse-Riding School, Short Stories). Frankfurt: Fischer Taschenbuch Verlag. 
Şengör, A. M. C. 1999. "Rumelili Hasan Tahsin" (Hasan Tahsin, a Hero From the Roumeli-Region). Cumhuriyet (Republic Newspaper), Bilim-Teknik Eki (Science and Technology Supplement), May 22, p. 1.

Tezcan, M. 1974. Türkler'le Illgili Stereotipler (Kalıp Yargılar) ve Türk Değerleri Üzerine Bir Deneme (An Essay on Streotypes Regarding Turks and Turkish Values). Ankara: Ankara University Printing-House.

\section{Bio}

Sinan Çaya, Ph.D., associate professor, Social Graduate Elective Courses, Institute of Marine Administration and Sciences, Istanbul University; research fields: rural sociology and peasant studies, military sociology, forensic social sciences, leadership, general education, social history, marine sociology, and marine organizational behavior. 